\title{
ZOOINDICATION AND ECOLOGICAL CONDITIONS OF THE VISTYNETSKOE LAKE
}

\author{
Maria Shibaeva \\ Evgeniya Pronkina \\ Julia Slepenkova \\ Olesija Elfimova \\ Evgeniya Matveeva \\ Elena Masjutkina \\ Kaliningrad state technical university, Russia
}

\begin{abstract}
The Vistynetskoe Lake has glacial origin and it is located in the south-eastern part of the Kaliningrad region. According to its natural status, the lake belongs to oligotrophic type of reservoirs with mesotrophic features.

The total surface area of the lake is $16.7 \mathrm{~km}^{2}$, with an average depth of $15.5 \mathrm{~m}$, and maximum length and maximum width $8.1 \mathrm{~km}$ and $4.2 \mathrm{~km}$ respectively. The latest researches in this are were carried out in summer 2006. The water quality was estimated pursuant to the Pantle and Bukk's method as modified by Sladechek, and Zooplankton, zoobentos and macrophyte organisms were used as bioindicators for ecological conditions of the lake.
\end{abstract}

By that period, 115 species of zooplankton were found, among them diaptomus Heterocope appendiculata.

Similar species of zooplankton dominate by number of species, by their biomass and their number is $3-4$.

143 species of zooplankton were found in the Vistynetskoe Lake during the whole research period.

Total area of the macrophyte overgrowth is less than $17 \%$ of the lake surface. Bushes have qualitative and quantitative differences in length and depth distribution. By the overgrowth the Vistynetskoe lake is similar to other bigger lakes in southern part of Lithuania.

The Chara, Pondweed, Elodea dominate among the submerged vegetation.

The saprobity index calculated for zoobentos and zooplankton does not exceed 1.6. It corresponds to oligo- $\beta$-mesosaprobic class of water quality. But there are some points where the level of saprobity changes to polysaprobic.

Thus, by the level of zooplankton and zoobentos development the Vistynetskoe lake is closer to mesotrophic type of reservoirs.

\section{KEYWORDS}

Oligotrophic, mesotrophic, water quality, the Pantle and Bukk's method as modified by Sladechek, Zooplankton, zoobentos, macrophytes, bioindicator, saprobity index 


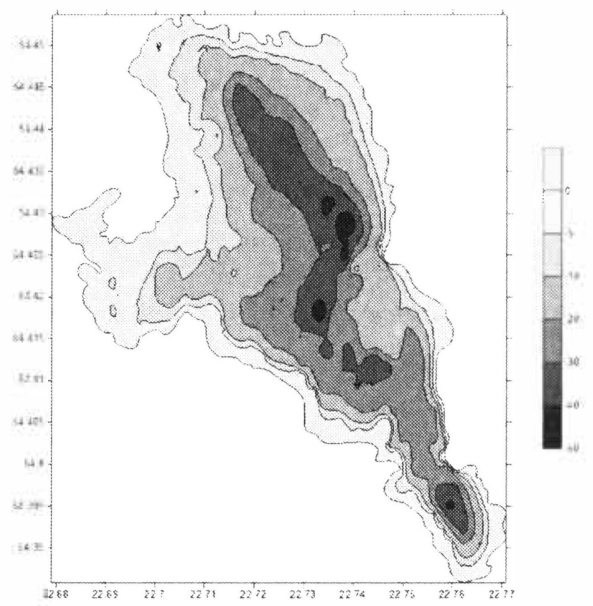

Figure 1. the Vistynetskoe Lake.

\section{INTRODUCTION}

The mesozooplankton and mesobenthos organisms have been chosen as the zoo indicators. The selection of samples at the Vishtynetskoye Lake was synchronously at 21 stations. Totally it was collected 21 samples of zooplankton and 21 samples of zoo benthos.

The samples of zooplankton were gathered by the medium model of the Jedi's net with diameter of entrance opening $0.26 \mathrm{~m}$. The gathering and processing were realized using generally accepted methodic $/ 9 /$. Period of gathering of samples was the ending of July - the beginning of August. It's the most representative period, when it's possible to find many species of zooplankton.

The samples of zooplankton were gathered on following weather conditions: ENE and NW wind. Strength of wind was from 1 up to 3 points; nebulosity was from 1 point in July to 10 points in August. Temperature of water was changing from 20 to $26^{\circ} \mathrm{C}$.

The gathering of zoobenthos was carried out with box-shaped bottonscoop of system of Peterson, with the area of capture of $1 / 40 \mathrm{~m}$. Processing carried out in laboratory was realized using generally accepted methodic $/ 9 /$, using appropriate qualifiers $/ 1-7,9-10 /$. The quantity of organisms was defined by direct account of organisms and biomass - by direct weighing on torsion scales (mark PRLT T4 №27004; year 1980).

\section{ZOOPLANKTON}

Zooplankton is an important part of ecological system of the Vishtynetskoye Lake.

It was found 29 species of invertebrate, among which are: Copepoda: Acanthodiaptomus denticornis, Cyclops abyssorum, C. etanoides, C. strenuus, Diaptomus castor, Eucyclops serrulatus, Eudiaptomus graciloides, Heterocope appendiculata, Macrocyclops albidus, Mesocyclops crassus, Microcyclops gracilis, copepodites, nauplyies, Cladocera: Bosmina longirostris, B. longispina, Bythotrephes longimanus, Ceriodaphnia affinis, Daphnia 
cucullata, Diaphanosoma brachyurum, Leptodora kindti, Leudigia leudigii, Moina sp, Rotatoria: Conochilus hippocrepis, Kellicottia longispina.

The spreading of species at the littoral water area was recognized: Daphnia cucullata, Bosmina longispina, Leudigia leudigii, Heterocope appendiculata, Diaptomus castor, Eucyclops serrulatus, etc.

The spreading of species at the supralittoral water area was following: Kellicottia longispina, Daphnia cucullata, Conochilus hippocrepis, Bosmina longispina, Heterocope appendiculata, Leptodora kindti, etc and at the open water area - Acanthodiaptomus denticornis, Heterocope appendiculata, Bythotrephes longimanus, Conochilus hippocrepis, Kellicottia longispina, Macrocyclops albidus, etc.

All occurred species are presented in the certain relation:

$\because$ Copepoda - $65 \%$, total 20 species,

Cladocera - $29 \%, 9$ species,

$\therefore$ Rotatoria - 6\%, 2 species.

The average quantity of zooplankton is low for the lake (354 specimen $/ \mathrm{m}^{3}$ ). The average biomass of zooplankton is not too big $-86 \mathrm{mg} / \mathrm{m} 3$.

Species dominant by quantity and biomass are: Daphnia cucullata, Heterocope appendiculata, Eucyclops serrulatus, Bosmina longispina, Diaptomus castor, Eudiaptomus graciloides, Cyclops strenuous.

To rare species were following: Cyclops abyssorum, Kellicottia longispina, Leptodora kindti.

\section{ZOOBENTHOS}

There were 42 species of zoobenthos organisms, among them there were: Oligochaeta - 5; Hirudinea - 4; Mollusca - 6; Crustacea - 2; Ephemeroptera - 2; Chironomidae - 19; Trichoptera -1 .

The most diversity of species has been registered at genus Chironomidae (19 species), the lack - Trichoptera- 1 .

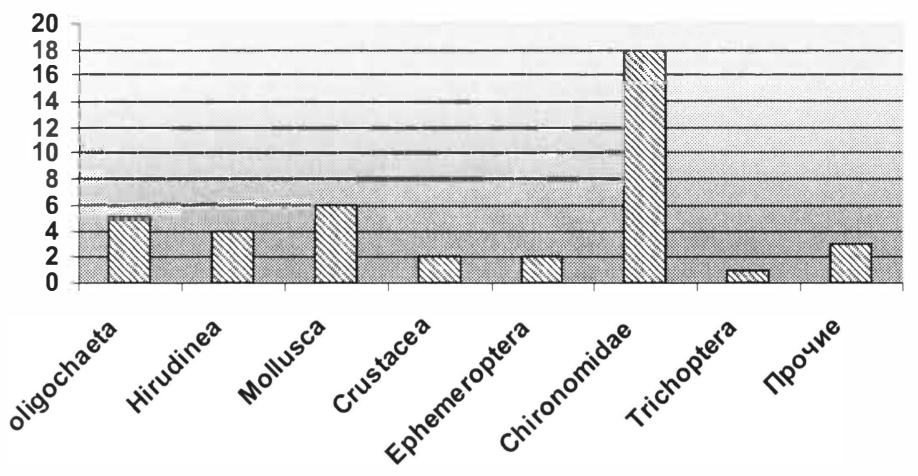

Fig.2. Diversity of zoobenthos' species 
The most occurred species at littoral and bathyal zones are mollusc, Oligochaeta and Chironomidae.

More rare occurred species at littoral are: Trichoptera and at bathyal: Trichoptera and leeches. Mayfly and some other species were found only at littoral zone.
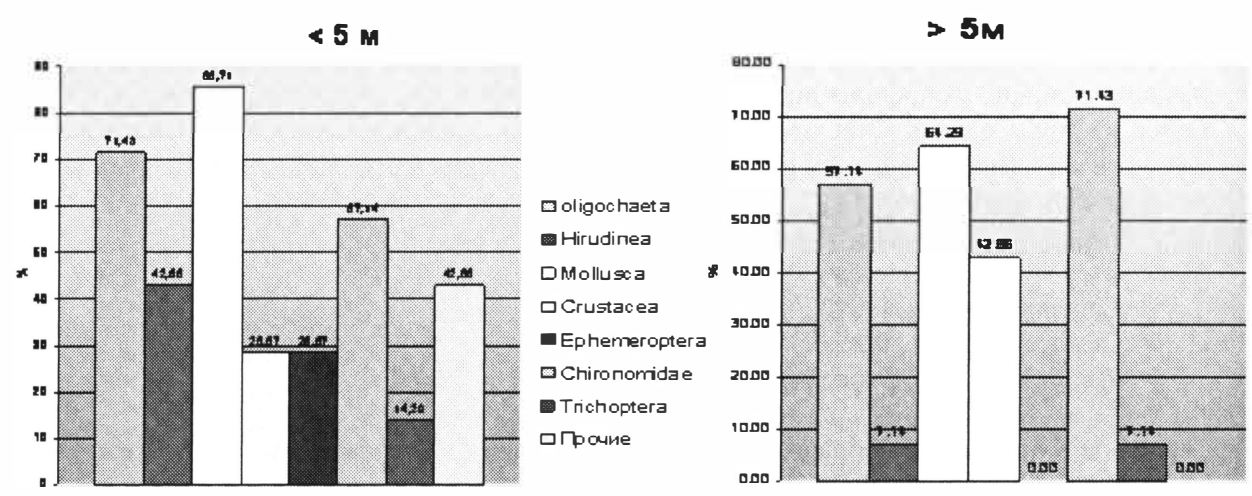

Fig.3. Frequency of single species being met at litoral and bathyal.

At the picture it's showed, that mollusca are dominating by quantity, but also there are lot of Chironomidae and Oligochaeta (see Figure. 3).

Mollusca are also dominating by biomass - they contain up to $90 \%$ (see Figure.4).

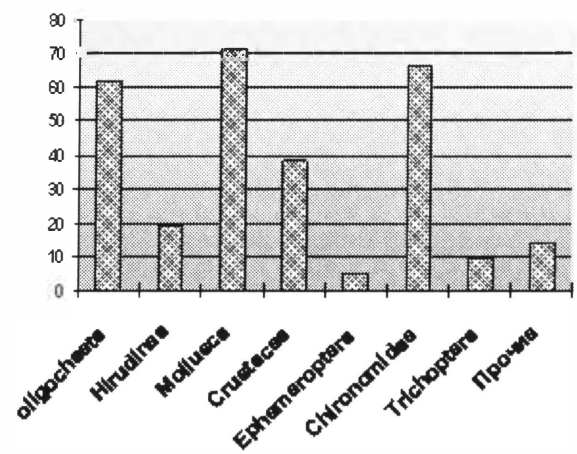

Fig.4. Average quantity of separate groups of zoobenthos.

The absolute quantity of zoobenthos is significantly varied between stations.

The most value of quantity of organisms was 2320 specimen $/ \mathrm{m}^{2}$. 


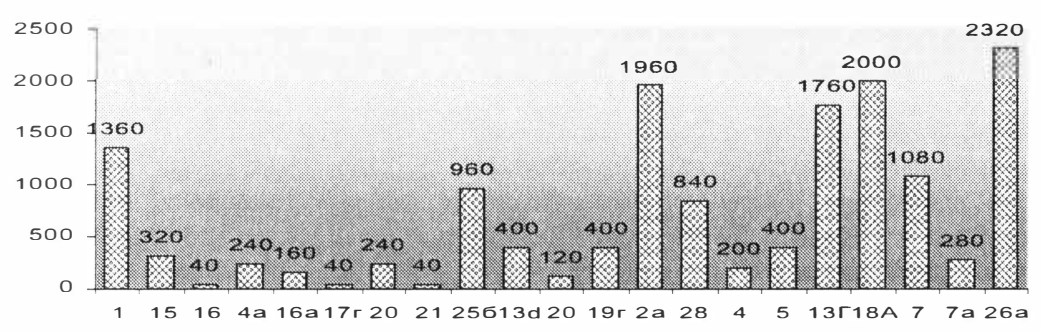

Fig. 5. Distribution of quantity of zoobenthos at the lake's bottom, specimen $/ \mathrm{m}^{2}$

Biomass of organisms at different stations is varied from 0.12 to $61,36 \mathrm{~g} / \mathrm{m}^{2}$. The highest level of biomass was noted at sublittoral $\left(61.36 \mathrm{~g} / \mathrm{m}^{2}\right)$. It's connected with dominating of mollusca at this station (see Figure.6).

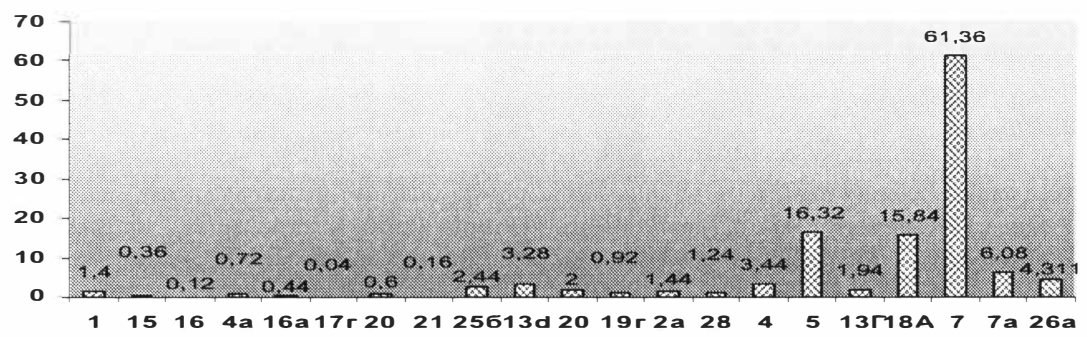

Fig. 6. Distribution of biomass of zoobenthos at the lake's bottom, $\mathrm{g} / \mathrm{m} 2$

Quantity and biomass of organisms at littoral and bathyal differ considerably. At littoral zone the favourable conditions for growth and life of organisms are created.
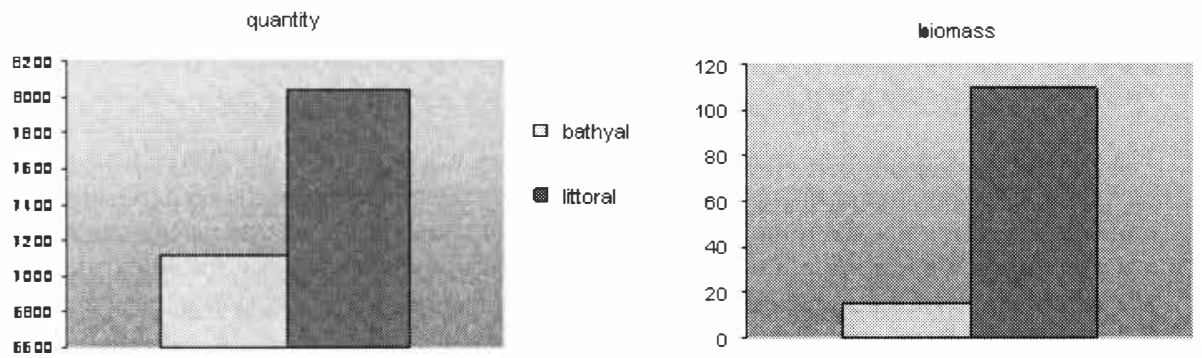

Fig. 7. Average value of quantity and biomass at bathyal and littoral 
The saprobity of the lake, defined using zoobenthos organisms, allows referring the lake's waters to pure enough and reasonably polluted. At the most of time dominates water of boligo class. But at littoral and bathyal there are areas with increased saprobity of a-meso and poly class.

\section{CHIRONOMIDAE}

The larvae of mosquito of Chironomidae - one of the numerous groups of freshwater invertebrates. Chironomidae has the longest period in larvae stage while their chrysalis and mosquito live only few days.

Larvae and chrysalis of Chironomidae have important role for feeding of freshwater fishes (bream, whitefish and others) and marine (cod) species.

It was found 16 species of Chironomidae which belong to 14 genus: (Procladius, Micropsectra, Chironomus, Criptochironomus, Cladotanytarsus, Tanypus, Limnochironomus, Psendochironomus, Microtendipes, Paratanytarsus, Anatopynia, Sergentia, Prodiamesa, Clinotanypus), and 4 species belong to subfamily Tanypodinae, 11 species to - subfamily Chironominae, 1 - subfamily Orthocladiinae

With changing of depth the inhabitance conditions, number and diversity of the Chironomidae is varied considerably. Therefore the researches have been held separately for littoral and bathyal zones.

In littoral zone, because of the more favourable conditions, the generic diversity is greater: there are 11 genera of Chironomidae (Procladius, Micropsectra, Chironomus, Criptochironomus, Cladotanytarsus, Tanypus, Limnochironomus, Psendochironomus, Microtendipes, Paratanytarsus, Anatopynia). The most spread Chironomidae at littoral zone are g. Procladius and g. Chironomus. The frequency of its occurrence is $75 \%$, and so they can be referred to constantly occurring genera. The most rarely Chironomidae are genus Cladotanytarsus, g. Tanypus, g. Paratanytarsus and g. Anatopynia with frequency of occurrence about $30 \%$.

In bathyal zone the Chironomidae of g. Sergentia can be referred to the constant species (the frequency of its occurrence is more than $80 \%$ ). The least frequent the Chironomidae are $\mathrm{g}$. Prodiamesa and g. Clinotanypus (its frequency less 10\%). Total in bathyal zone was found 6 genera of Chironomidae: g. Procladius, g. Micropsectra, g. Chironomus, g. Sergentia, g. Prodiamesa, g. Clinotanypus.

The 5th station is the poorest station in the littoral zone. It's situated in the Tihaya Bay, which looked as a shallow reservoir sufficiently isolated from the main part of the lake. At a present time active eutrophication processes are observed in the bay, that are accompanied by overgrowing and dying off of coastal and water-coastal vegetation. There are only 2 generas of Chironomidae: Chironomus and Tanypus on this station, with domination of the genus Chironomus.

There are some stations in bathyal zone, where only one genus of Chironomidae was found. For example, at 1,28 and $17 \mathrm{~g}$ stations Chironomidae of genus Sergentia were found. These stations are situated on the great depths. 
Thus, the larvae of Chironomidae are spreaded on the lake's bedding irregularly. Spottiness and mosaicness are observed in its distribution. As it's been noticed above, the larvae of Chironomidae can be used as an indicator of the purity of water.
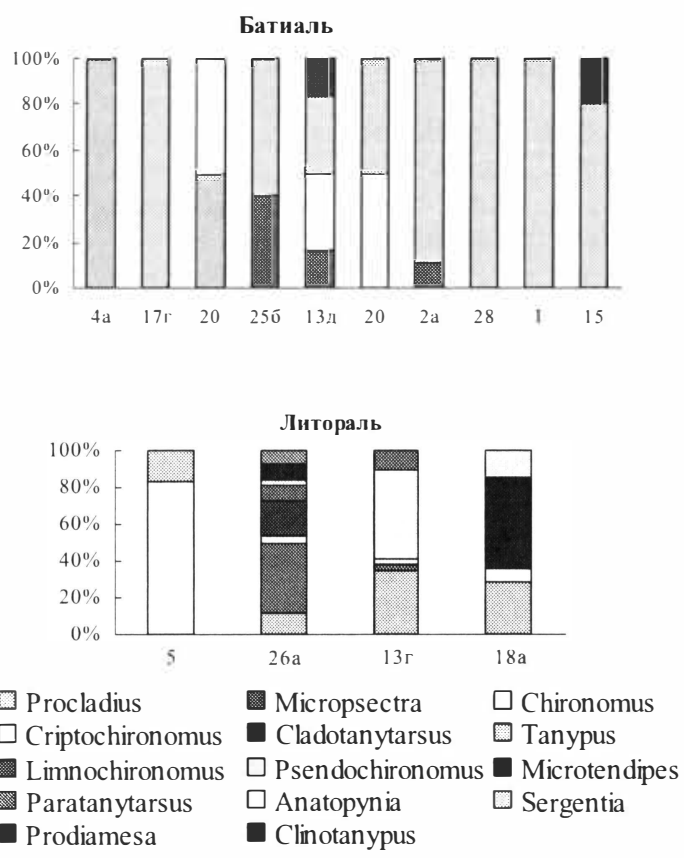

Fig.8. Distribution of quantity of Chironomidae at the lake's Vishtynetskoye bedding

\section{CONCLUSIONS}

By the progress level of zooplankton the lake is of oligotrophic with traits of mesotrophicity type of reservoirs.

Dominant species of zooplankton are: Daphnia cucullata, Heterocope appendiculata, Eucyclops serrulatus, Bosmina longispina, Diaptomus castor, Eudiaptomus graciloides, Cyclops strenuous.

Type of waters - oligo- $\beta$-mesosaprobic.

Total quantity of zoobenthos species all over the lake for 2006 is 42 species.

Occurrence of species at the reservoir's bedding is irregular. The most of them was found in littoral and sublittoral.

Distribution of species at the lake is irregular and mosaic.

Quality of water by index of saprobity using Pantle and Bookke method in Sladechek's modification at an average doesn't exceed 1.5. Therefore the lake can be referred to an oligosaproic class, i.e. its water is pure. But there is a station (st. 5), where index of saprobity is up to 2,87 - it's $\alpha$-mesosaprobic zone. 
By the Balushkina's index waters of Vishtynetskoye lake can be referred to reasonably pollute.

\section{REFERENCES}

[1] Zhadin V.I. Mollusca of fresh water of USSR. -M.-L.: AN USSSR, 1952. - 375 p.

[2] Lipin A.N. Life in freshwater bodies. - M.: AN USSSR, 1950. - 347 p.

[3] Lukin E.I. Leechs of fresh and saltish water bodies // Fauna of USSSR. -T.1. -M.-L.: Science, 1964. -484 p.

[4] Qualifier of invertebrates in fresh water bodies European part of USSSR. - L.: hydrometeoizdat, 1977. - $511 \mathrm{p}$.

[5] Pankratova V.Y. Larvae and chrysalices gnats (Orthocladiinae) of USSSR's fauna (Diptera, Chironomidae, Tendipedidae). -L.: Science, 1970. - 344 pc.

[6] Pankratova V.Y. Larvae and chrysalices gnats (Podonominae, Tanypodiae) of USSSR's fauna (Diptera, Chironomidae, Tendipedidae). -L.: Science, 1970. - 152 p.

[7] Determination manual in hydrobiology method's of superficial water and bottom sediments. - L.: hydrometeoizdat, 1983.-238 p.

[8] Chekanovskaya O.V. Aquatic Oligochaeta of USSSR's fauna. -M.-L.: AN USSSR, 1962. $-411 \mathrm{p}$.

[9] Chernovski A.A. Qualifier of Tendipedidae. -M.-JI.: ZIN AN USSSR P. 1949. - 162 p.

[10] Shibaeva M.N. Ecological characteristic of smaller rivers in Kaliningrad region. abstract to Ph.D. thesis. Kaliningrad: 1997. 24 p. 